\title{
REGIONAL ANALYSIS OF NEW EU MEMBER STATES IN THE CONTEXT OF COHESION POLICY
}

Milan Viturka, Vladimír Žítek, Viktorie Klímová, Petr Tonev

Ekonomicko-správní fakulta Masarykovy univerzity, katedra regionálního rozvoje a správy, Lipová 41a, 60200 Brno (viturka@econ.muni.cz; zitek@econ.muni.cz; Viktorie.Klimova@econ.muni.cz; Petr.Tonev@econ.muni.cz)

\begin{abstract}
The paper concentrates on the new European Union member states, i.e. the states of central and eastern Europe which entered the Union in 2004 (Czech Republic, Slovakia, Poland, Hungary, Lithuania, Latvia, Estonia and Slovenia) and 2007 (Bulgaria and Romania). The basis of the paper is the evaluation of the cohesion policy in the countries in question, which are then analysed at the level of NUTS 2 regions (cohesion regions). The aim of the socioeconomic analysis is to assess the economic level of the regions and to use the results to form their typology. Ten characteristic indicators were chosen so that the study was as complex as possible. For each indicator in the examined countries the average was calculated, which allowed for a considerable increase of the information relevance of the study conclusions. For the cartographic representation of the regional differentiation intervals based on this average and the standard deviation were used. The final part of the study presents a concluding synthesis together with the above-mentioned typology of the regions. The results are interpreted in the context of the optimal strategy selection for the regional policy determined by the EU cohesion policy.
\end{abstract}

Key words: region, regional disparities, socioeconomic development, cohesion policy, new member states,

JEL classification: 018, R11, R58

DOI: $10.2478 / \mathrm{v} 10135-009-0001-8$

Národohospodářský obzor - Review of Economic Perspectives

ISSN 1804-1663 (Online), ISSN 1213-2446 (Print)

http://nho.econ.muni.cz/en

(C) Masarykova univerzita 


\title{
REGIONAL ANALYSIS OF NEW EU MEMBER STATES IN THE CONTEXT OF COHESION POLICY
}

\author{
Milan Viturka, Vladimír Žítek, Viktorie Klímová, Petr Tonev ${ }^{1}$
}

\section{Introduction}

The regional analysis focuses on the new member states of the European Union, i.e. the central and eastern European countries which entered the Union in 2004 (Czech Republic, Slovakia, Poland, Hungary, Lithuania, Latvia, Estonia and Slovenia) and 2007 (Bulgaria and Romania). The listed states are analysed at the level of NUTS 2 (cohesion regions). The main reason why this level has been chosen is the availability of statistical data [7]. The authors also want to point out that there are some limitations to the information relevance of the presented data as the NUTS 2 units are in most countries created artificially and they do not represent natural functional regions. Moreover, four of the countries (Lithuania, Latvia, Estonia and Slovenia) are not divided at this level at all. ${ }^{2}$ In spite of this fact, the conclusions of the study can be considered valuable and providing sufficient information on the economic level of the regions.

There are the following 53 regions at NUTS 2 level in the ten examined states:

- Bulgaria (6) - Severozapaden, Severen Centralen, Severoiztočen, Jugoiztočen, Jugozapaden, Južen Centralen;

- Czech Republic (8) - Praha, Střední Čechy, Jihozápad, Severozápad, Severovýchod, Jihovýchod, Střední Morava, Moravskoslezsko;

- Estonia (1);

- $\quad$ Lithuania (1);

- Latvia (1);

- Hungary (7) - Közép-Magyarország, Közép-Dunántúl, Nyugat-Dunántúl, DélDunántúl, Észak-Magyarország, Észak-Alföld, Dél-Alföld;

- Poland (16) - Lódzkie, Mazowieckie, Malopolskie, Slaskie, Lubelskie, Podkarpackie, Swietokrzyskie, Podlaskie, Wielkopolskie, Zachodniopomorskie, Lubuskie, Dolnoslaskie, Opolskie, Kujawsko-Pomorskie, Warminsko-Mazurskie, Pomorskie;

- Romania (8) - Nord-Vest, Centru, Nord-Est, Sud-Est, Sud-Muntenia, BucurestiIlfov, Sud-Vest Oltenia, Vest;

- $\quad$ Slovenia (1);

- Slovakia (4) - Bratislavský kraj, Západné Slovensko, Stredné Slovensko, Východné Slovensko.

1 Department of Regional Economics and Administration, Faculty of Economics and Administration, Masaryk University, Lipová 41a, 60200 Brno.

${ }^{2}$ Since 1/1/2008 Slovenia has been divided into two NUTS 2 units. 


\section{Objectives and Methodology}

In the first part of this article the authors present brief summary of cohesion policy. This summary serves as the ground for analysis of NUTS 2 regions and also as the basis for formulation of conclusions.

The objective of the socioeconomic analysis was to assess the economic level of the regions and to use the analysis results to form their typology. Ten various indicators were chosen for the socioeconomic analysis. As the year 2005 is the last one for which all statistical data is available, it was chosen as the key year. The values of this year were taken into account for the indicators which do not show any significant fluctuations (employment). For the indicators where using values of one year only could mean significant distortion, the average value of the years 2003-2005 was used for the analysis. If the average of the entire EU (EU27) was available, the data of the examined regions were compared with this value. Similarly, if the information was available for the original fifteen states (EU15), the analysed data were compared with the average of these developed member states. Further, the average of all the examined countries was calculated for each indicator, marked CE10 in the text below, which allowed for a considerable increase of the information relevance of the study conclusions. For the cartographic representation of the regional differentiation of the indicators, intervals based on the average and the standard deviations were used. The statistical data were obtained from the regional statistical database Eurostat.

The final part of the paper presents the regional synthesis of the development potential of the chosen countries CE10. The main objective of the synthesis is to provide general information on the development potential of the countries in question, or rather their regions. The methodological procedure is based on the evaluation of the following components of socioeconomic development: economic components (GDP per inhabitant and labour productivity), components concerning sectors (proportions of the employed in agriculture, research and development, and knowledge-intensive services), components concerning innovation (expenditures on research and development), social components (unemployment rate and disposable household income), and demographic components (natural population growth and migration). The regions were evaluated with 1-5 points for each of the components (the more, the better) according to their position in the intervals set on the basis of the average and the standard deviation (the procedure within individual components consisting of more indicators was analogical). As the next step, the aggregation of the partial evaluation results was carried out by calculating the arithmetic average of the points gained for the five listed components i.e. the resulting evaluation could range between 1.0 and 5.0.

\section{Implementation of Cohesion Policy in the Examined Countries}

The economic and social cohesion policy, or the EU cohesion policy (sometimes also the regional or structural policy), is one of community policies which are implemented by individual member states, whereas their coordination and harmonization is a responsibility of the appropriate Union institutions. The main strategic objective of this policy is the minimization of economic and social disparities between regions. Furthermore, the cohesion policy is influenced by the existing basic development trends, mainly the accelerating structural changes in national economies (conditioned also by the globalization and the economic and institutional integration), the growing 
significance of the mobilization of internal (regional) resources of economic development and the continuous shift of the regional policy focus from central institutions of public administration to regional institutions of public administration, especially self-government. Considering the amount of the allotted means, the cohesion policy represents the most significant EU policy in the new programming period 20072013 - the total amount is EUR 347 billion.

The cohesion policy is financed from structural funds, i.e. the European Regional Development Fund (ERDF) and the European Social Fund (ESF), together with the Cohesion Fund (CF). The practical implementation of the regional policy is carried out using development programmes (operational programmes) which include several fields and last for several years, thus exceeding the length of election terms. Three objectives have been set for the period of 2007-2013 [2]:

- The Convergence Objective - especially NUTS 2 regions whose gross domestic product per inhabitant is lower than $75 \%$ of the average GDP per inhabitant of EU25 are eligible to draw on the support under this objective.

- The Regional Competitiveness and Employment Objective - all the regions which do not fall under the Convergence Objective are eligible to draw on the support under this objective.

- The European Territorial Cooperation Objective - this objective serves all the regions in the total area of the EU.

From the point of view of the allotted financial means the Convergence Objective is the most significant (weight $81.54 \%$ ), followed by the Regional Competitiveness and Employment Objective (weight $15.95 \%$ ). [2] In the countries analysed in this paper all NUTS 2 regions fall under the Convergence Objective except Praha, Bratislavský kraj and Hungarian Közép- Magyarország.

An operational programme is a basic strategic document of a financial and technical character and it serves the purpose of drawing on the means from structural funds. It focuses either on a thematic field (e.g. entrepreneurship, employment, transport etc.) or a specific cohesion region (i.e. a NUTS 2 region). [11] Each operational programme is financed from the EU contributions and contributions from the country in question. Operational programmes can be divided into three basic groups depending on the objective in which they are included:

- the operational programmes under the Convergence Objective (financed from the ERDF, ESF and CF),

- the operational programmes under the Regional Competitiveness and Employment Objective (financed from the ERDF a ESF), and

- the operational programmes under the European Territorial Cooperation Objective (financed from the ERDF).

The table 1 shows the financial allocation to the examined countries with respect to individual objectives of the Economic and Social Cohesion Policy. Calculating the allocated means per inhabitant, we find out that most means of the examined countries (and of all EU states) were obtained by the Czech Republic. 
Table 1: Financial Allocation 2007-2013 (in million EUR, common prices)

\begin{tabular}{|l|r|r|r|r|c|}
\hline $\begin{array}{l}\text { Country / } \\
\text { Objective }\end{array}$ & Convergence & $\begin{array}{l}\text { Regional } \\
\text { Competitiveness } \\
\text { and Employment }\end{array}$ & $\begin{array}{l}\text { European } \\
\text { Territorial } \\
\text { Cooperation }\end{array}$ & Total & $\begin{array}{l}\text { per } \\
\text { inha- } \\
\text { bitant }\end{array}$ \\
\hline CR & 25883 & 419 & 389 & 26692 & 2599 \\
\hline Slovakia & 10912 & 449 & 227 & 11588 & 2149 \\
\hline Hungary & 22890 & 2031 & 386 & 25307 & 2513 \\
\hline Poland & 66553 & - & 731 & 67284 & 1764 \\
\hline Slovenia & 4101 & - & 104 & 4205 & 2095 \\
\hline Lithuania & 6775 & - & 109 & 6885 & 2029 \\
\hline Latvia & 4531 & - & 90 & 4620 & 2019 \\
\hline Estonia & 3404 & - & 52 & 3456 & 2572 \\
\hline Bulgaria & 6674 & - & 179 & 6853 & 890 \\
\hline Romania & 19213 & - & 455 & 19668 & 911 \\
\hline
\end{tabular}

Source: European Commission [6], Eurostat - Population [8], authors' calculations

The ten European Union states analysed draw approximately $51 \%$ of the total budget of the Economic and Social Cohesion Policy. The share of the Convergence Objective budget these states obtain is even higher $-60 \%$ of its means. As far as the Regional Competitiveness and Employment Objective is concerned, they draw $5 \%$ of the budget; and in the European Territorial Cooperation Objective their share is $31 \%$. Table 2 presents the figures relevant to the operational programmes under the Convergence Objective in individual countries and the financial percentage of the programmes out of the total contribution from EU.

Table 2: Operational programmes in the framework of the Convergence Objective in individual countries

\begin{tabular}{|c|c|c|c|c|c|c|}
\hline \multirow{2}{*}{$\begin{array}{c}\text { Country / } \\
\text { OP }\end{array}$} & \multicolumn{2}{|c|}{$\begin{array}{c}\text { Thematic OP (ERDF, } \\
\text { CF) }\end{array}$} & \multicolumn{2}{|c|}{ Regional OP (ERDF) } & \multicolumn{2}{|c|}{ OP financed from ESF } \\
\hline & $\begin{array}{c}\text { number } \\
\text { of OP }\end{array}$ & $\begin{array}{c}\% \text { of } \\
\text { contribution }\end{array}$ & $\begin{array}{c}\text { number } \\
\text { of OP }\end{array}$ & $\begin{array}{c}\% \text { of } \\
\text { contribution }\end{array}$ & $\begin{array}{c}\text { number } \\
\text { of OP }\end{array}$ & $\begin{array}{c}\% \text { of } \\
\text { contribution }\end{array}$ \\
\hline $\mathbf{C R}$ & 6 & 66.07 & 7 & 17.45 & 2 & 13.73 \\
\hline Slovakia & 6 & 61.44 & 1 & 12.47 & 2 & 12.94 \\
\hline Hungary & 5 & 51.47 & 6 & 17.01 & 2 & 14.34 \\
\hline Poland & 4 & 57.90 & 16 & 24.61 & 1 & 14.43 \\
\hline Slovenia & 2 & 79.56 & - & - & 1 & 17.97 \\
\hline Lithuania & 2 & 83.48 & - & - & 1 & 13.58 \\
\hline Latvia & 2 & 86.15 & - & - & 1 & 11.92 \\
\hline Estonia & 2 & 85.52 & - & - & 1 & 11.33 \\
\hline Bulgaria & 5 & 80.08 & - & - & 2 & 17.30 \\
\hline Romania & 5 & 78.96 & - & - & 2 & 18.73 \\
\hline
\end{tabular}

Note: \% of contribution expresses the share of the type of operational programmes in the total contribution to the state from the EU (see table 1). The amount remaining to $100 \%$ represents the contribution to the member state within the framework of the European Territorial Cooperation Objective.

Source: European Commission [5] [6], authors' calculations 
The examined countries can be divided into three basic groups. The first group is the Visegrad Four states. These states are divided into statistical units NUTS 2 and special regional operational programmes are created for each of these regions. The only exception is Slovakia, which has only created one regional operational programme for all convergence regions (i.e. the entire SR except Bratislavský kraj). There are also developed regions which fall within the Regional Competitiveness and Employment Objective in the V4 states - except Poland - and these are supported from special operational programmes. The second group consists of Slovenia, Lithuania, Latvia and Estonia, which entered the EU in 2004 as well as the V4 states, but in contrast to the V4 states these are not divided into statistical units NUTS 2 and the entire areas of these states fall under the Convergence Objective only. It follows that these states do not create regional operational programmes or operational programmes for the Regional Competitiveness and Employment Objective. The last group includes Bulgaria and Romania - the states which entered the EU as late as in 2007. These countries are divided into NUTS 2 units but they do not create special regional programmes for them. There is no developed region in Bulgaria or Romania to be included in the Regional Competitiveness and Employment Objective. The financial support to these states calculated per inhabitant is considerably lower than in the remaining eight states.

Within the framework of the Convergence Objective most states have independent programmes focusing on the development of transport and the environment and the largest part of the financial means is allotted to these activities. However, these fields are also the priorities of the entire EU [4] and also a special fund (the Cohesion Fund) was established for their financing. Other frequently supported fields are the entrepreneurship and innovations and the information and communication technologies (incl. public administration computerization). The Czech Republic is the only one that has an independent operational programme focusing on research and development and also the Integrated Operational Programme. Slovakia has a special programme to support health care. The health care in the CR can be supported in the framework of a priority in the Integrated Operational Programme. The Czech regional operational programmes focus on three basic areas which are the regional transport infrastructure, tourism, and the development of cities, towns and the country. Investments in health care and social services can be financed from them only exceptionally. The regional operational programmes in the other states have a larger scale. Besides the transport infrastructure, the development of cities and tourism, they often support the entrepreneurship, innovations, social services, health care and the environment.

The EU cohesion policy is probably the most accepted practical example of the existing solidarity among the member states and in correspondence with its proved flexibility and the quite well developed control mechanisms it has its solid place in the system of EU policies. [3] Concerning the complicated issue of the evaluation of the specific contribution the development programmes bring, it is necessary to say that even the most renowned economic centres do not possess generalized methodological procedures which would clearly define the contributions of the public programmes to the economic development of individual countries and their regions.

\section{Socioeconomic Analysis of NUTS 2 Regions}

The following 10 indicators were chosen so that the study was as complex as possible: 
- $\quad$ natural population growth;

- migration;

- $\quad$ regional gross domestic product;

- labour productivity;

- disposable household income;

- unemployment rate;

- employment in agriculture;

- employment in knowledge-intensive services;

- employment in research and development;

- $\quad$ expenditures on research and development.

\section{Natural Population Growth}

This basic demographic indicator is calculated from the number of newborns and the number of the deceased per 1000 inhabitants. The countries of central and eastern Europe are characteristic for a decreasing death rate and also a very low birth rate. This is reflected in the values of the natural population growth. The average values of the primary indicators at level of EU27 or EU15 are not available for analysis.

The highest values of this indicator are achieved in Polish regions. Eight (!) regions out of the first ten regions, which also represent all the regions with positive values of natural population growth, are Polish. The first is Východné Slovensko, however, Polis Pomorie reaches the same values of 4.63. The other non-Polish region in the first ten is Romanian Nord-Est with the value of 1.77 in seventh place.

Table 3: Natural population growth (per 1000 inhabitants, the average value of the years 2003-2005)

\begin{tabular}{|ll|c|}
\hline \multicolumn{2}{|l|}{ region NUTS 2 } & $\begin{array}{c}\text { natural population } \\
\text { growth }\end{array}$ \\
\hline SK04 & Východné Slovensko & 4.63 \\
\hline PL63 & Pomorskie & 4.63 \\
\hline PL41 & Wielkopolskie & 3.63 \\
\hline PL21 & Malopolskie & 3.53 \\
\hline PL32 & Podkarpackie & 2.47 \\
\hline PL62 & Warminsko-Mazurskie & 2.40 \\
\hline RO21 & Nord-Est & 1.77 \\
\hline PL61 & Kujawsko-Pomorskie & 1.00 \\
\hline PL42 & Zachodniopomorskie & 0.80 \\
\hline PL43 & Lubuskie & 0.73 \\
\hline
\end{tabular}

Source: Eurostat - Regional statistics [9], authors' calculations

The lowest natural population growth was found out in Romanian Sud-Muntenia (12.87), Latvia (-11.47), Lithuania (-11.43), Bulgarian Severozapadem (-10.30). 43 NUTS 2 regions, among which there are all the eight Czech regions, achieved a negative growth in the average of 2003-2005. On the other hand, it is necessary to note that the Czech regions are above the average of CE10, which is -3.57 (altogether, 29 units are above average). 


\section{Migration}

To a great extent migration values provide evidence on the attractiveness of the region in question. If the region can gain population by migration, we can assume that it has vacancies and therefore a potential for further development. The indicator is calculated from the interannual differences of the population of NUTS 2 units after the natural population growth is taken into account. Like in the case of the natural population growth indicator, the values of EU15 and EU27 are not available.

Table 4: Migration (per 1000 inhabitants, the average value of the years 2003-2005)

\begin{tabular}{|ll|c|}
\hline \multicolumn{2}{|l|}{ region NUTS 2 } & migration \\
\hline HU10 & Közép-Magyarország & 13.38 \\
\hline BG41 & Jugozapaden & 12.00 \\
\hline CZ02 & Střední Čechy & 10.11 \\
\hline RO31 & Sud-Muntenia & 8.19 \\
\hline CZ01 & Praha & 7.56 \\
\hline RO32 & Bucuresti-Ilfov & 6.24 \\
\hline LV00 & Lotyšsko & 6.18 \\
\hline LT00 & Litva & 5.71 \\
\hline PL12 & Mazowieckie & 5.32 \\
\hline RO41 & Sud-Vest Oltenia & 5.08 \\
\hline
\end{tabular}

Source: Eurostat - Regional statistics [9], authors' calculations

Positive migration balance in the examined period was achieved by 30 regions, the CE10 average is 2.09 inhabitants per 1000 inhabitants (21 out of the regions are above the average). The first ten is headed by Hungarian Közép-Magyarország, Bulgarian Jugozapaden and Czech Střední Čechy, all of them with a value exceeding 10.00. Furthermore, there are three Romanian NUTS 2, Czech Praha region, Latvia and Lithuania, and Polish Mazowieckie.

The ten regions with the worst balance are headed by Moravskoslezsko (-1.89), by the way the only Czech region with a negative migration balance, followed by five Polish regions (from -1.93 to -3.54$)$, two Bulgarian regions (-2.17 and -6.50$)$, Východné Slovensko (-2.57) and Romanian Nord-Est (-2.78).

\section{Regional Gross Domestic Product}

The gross domestic product is the key indicator of the structural (regional) policy and undoubtedly the most significant indicator of the economic level of a region. For analysis the regional GDP was used in the purchasing power parity per inhabitant, expressed as a percentage of the EU27 average $(E U 27=100 \%)$. Especially the value of $75 \%$ is important for the new member states.

The dominant position is taken by three regions - the most developed capitals - Praha, Bratislava (Bratislavský kraj) and Budapest (Közép-Magyarország), which exceed the value of EU27, Praha and Bratislavský kraj also exceed the value of EU15 (113.2 \%). The mentioned $75 \%$ are also exceeded by Slovenia and Polish Mazowieckie. The first ten are completed by three Czech regions (Střední Čechy, Jihozápad and Jihovýchod), Romanian Bucuresti-Ilfov and Hungarian Nyugat-Dunántúl. The remaining Czech regions are in 11th, 12th, 13th and 15th places. 
Table 5: Regional gross domestic product (\% of the EU27 average in the PPP per inhabitant, the average value of the years 2003-2005)

\begin{tabular}{|ll|c|}
\hline \multicolumn{2}{|l|}{ region NUTS 2 } & regional GDP \\
\hline CZ01 & Praha & 156.5 \\
\hline SK01 & Bratislavský kraj & 134.1 \\
\hline HU10 & Közép-Magyarország & 101.7 \\
\hline SI00 & Slovinsko & 84.8 \\
\hline PL12 & Mazowieckie & 78.2 \\
\hline CZ02 & Střední Čechy & 70.5 \\
\hline CZ03 & Jihozápad & 68.9 \\
\hline CZ06 & Jihovýchod & 67.4 \\
\hline RO32 & Bucuresti-Ilfov & 66.7 \\
\hline HU22 & Nyugat-Dunántúl & 66.3 \\
\hline
\end{tabular}

Source: Eurostat - Regional statistics [9], authors' calculations

The CE10 average is, by coincidence, close to $50 \%$, precisely $50.4 \%$. Most regions (32) are below this value. The worst economic efficiency is to be found in Romanian and Bulgarian regions (there are five of each within the worst ten). Their regional GDP reaches only $32.4-23.5 \%$ of the EU27 average. 
Figure 1: Regional Gross Domestic Product

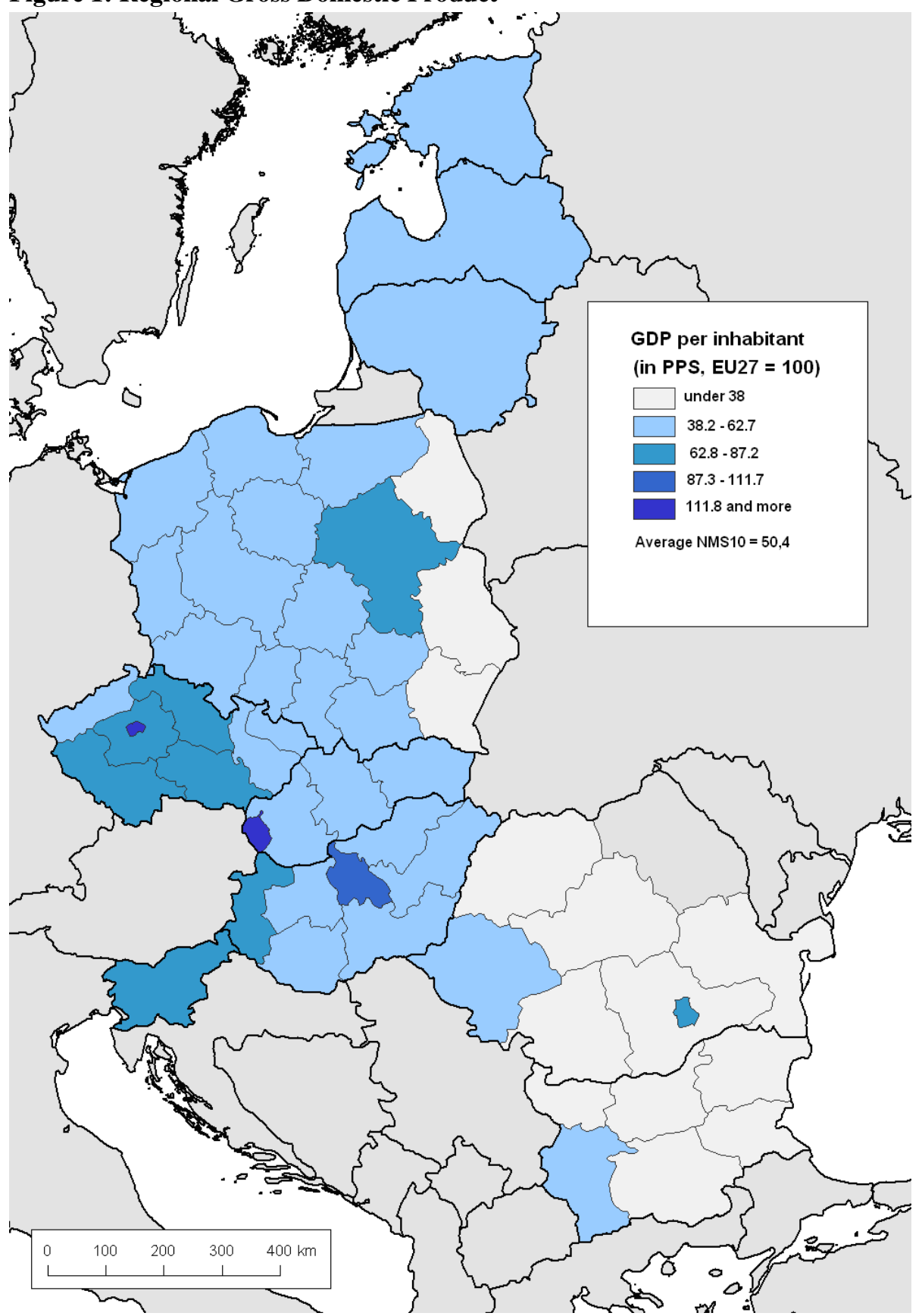

Source: created by authors on the basis of Eurostat - Regional statistics [9] 


\section{Labour Productivity}

One of the ways to measure labour productivity at regional level is to recalculate the regional GDP to the employed persons in the region. [7] This calculation uses absolute values of GDP in EUR, the indicator itself is expressed in thousands EUR. Although the data for the EU27 (50.78 thousand EUR) and EU15 (59.79 thousand EUR) average are available, they are of an informative character only as they are too far from the average values of central and eastern Europe.

The highest labour productivity is achieved by Praha (35.26 thousand EUR), Hungarian Közép-Magyarország (30.05 thousand EUR), Slovenia and Bratislavský kraj. The ten most productive regions are joined by two Hungarian and four Polish regions. The 11th to the 14th places are occupied by Czech regions in the order of Jihovýchod, Střední Čechy, Moravskoslezsko and Jihozápad. The CE10 average is 14.00 thousand EUR. 25 regions in total are above this value, all the eight Czech regions being among them.

Table 6: Labour productivity (GDP/ employment in thousands EUR, the average value of the years 2003-2005)

\begin{tabular}{|ll|c|}
\hline \multicolumn{2}{|l|}{ region NUTS 2 } & $\begin{array}{c}\text { labour } \\
\text { productivity }\end{array}$ \\
\hline CZ01 & Praha & 35.26 \\
\hline HU10 & Közép-Magyarország & 30.05 \\
\hline SI00 & Slovinsko & 28.78 \\
\hline SK01 & Bratislavský kraj & 28.63 \\
\hline PL12 & Mazowieckie & 23.01 \\
\hline HU22 & Nyugat-Dunántúl & 19.85 \\
\hline HU21 & Közép-Dunántúl & 18.35 \\
\hline PL22 & Slaskie & 17.90 \\
\hline PL63 & Pomorskie & 17.50 \\
\hline PL51 & Dolnoslaskie & 17.44 \\
\hline
\end{tabular}

Source: Eurostat - Regional statistics [9], authors' calculations

Fourteen NUTS 2 regions reach lower labour productivity than 10 thousand EUR. With one exception only, they are all Romanian (all Romanian regions except Bucuresti-Ilfov, which is slightly below the CE10 average) and Bulgarian (all of them).

\section{Disposable Household Income}

Eurostat statistics differentiate between two kinds of income - the primary and the disposable income. The disposable income was chosen for the analysis as it more suitably expresses the real purchasing power of the population. The disposable income includes all incomes after taxation and deduction of insurance fees, further it includes accepted social transfers. [1] The average values of the indicator for EU27 or EU15 are not available, nor are the values of Bulgarian regions.

The highest disposable income is obtained by the inhabitants of Slovenia - 7,874 EUR, which is an amount higher by $20 \%$ than in the region in second place, Hungarian Közép-Magyarország. Praha (5,955 EUR) and Bratislavský kraj (5,583 EUR) follow. The fifth highest value is achieved by Polish Mazowieckie with practically the same value as Střední Čechy in sixth place. In the first ten, there are also Czech Jihozápad and 
Jihovýchod regions. The 15th place is occupied by the 'worst' of the Czech NUTS 2 Severozápad (3,891 EUR). 26 regions in total are above the CE10 (or rather CE9) average, which is 3,458 EUR per inhabitant.

Table 7: Disposable household income (in EUR per inhabitant, the average value of the years 2003-2005)

\begin{tabular}{|ll|c|}
\hline \multicolumn{2}{|l|}{ region NUTS 2 } & household income \\
\hline SI00 & Slovinsko & 7874 \\
\hline HU10 & Közép-Magyarország & 6405 \\
\hline CZ01 & Praha & 5955 \\
\hline SK01 & Bratislavský kraj & 5583 \\
\hline PL12 & Mazowieckie & 4685 \\
\hline CZ02 & Střední Čechy & 4671 \\
\hline CZ03 & Jihozápad & 4294 \\
\hline HU22 & Nyugat-Dunántúl & 4272 \\
\hline CZ06 & Jihovýchod & 4191 \\
\hline HU21 & Közép-Dunántúl & 4157 \\
\hline \multicolumn{2}{|l|}{ Source: Eurostat - Regional statistics [9], authors' calculations }
\end{tabular}

The order of the regions inhabitants of which disposed with incomes lower than 3,000 EUR is headed by Latvia (2,919 EUR), followed by Romanian Bucuresti-Ilfov (2,849 EUR) and Polish Podkarpackie (2,822 EUR). The last seven places are occupied by Romanian regions, where the disposable income ranges between 2,050 EUR and 1,401 EUR per inhabitant.

\section{Unemployment Rate}

The International Labour Organization (and the Eurostat methodology [7]) defines an unemployed worker as someone who is older than 15 , actively seeking work and able to start a job immediately or within 14 days. The unemployment rate is generally the most available indicator, as it is followed closely by all member states. Its static values, and their changes, are interesting not only for research but they are also important for the implementation of an economic policy.

Table 8: Unemployment rate (in \%, the average value of the years 2003-2005)

\begin{tabular}{|ll|c|}
\hline \multicolumn{2}{|l|}{ region NUTS 2 } & unemployment rate \\
\hline CZ01 & Praha & 3.9 \\
\hline HU10 & Közép-Magyarország & 4.5 \\
\hline HU22 & Nyugat-Dunántúl & 5.0 \\
\hline CZ02 & Střední Čechy & 5.3 \\
\hline CZ03 & Jihozápad & 5.4 \\
\hline HU21 & Közép-Dunántúl & 5.5 \\
\hline RO21 & Nord-Est & 6.1 \\
\hline RO11 & Nord-Vest & 6.1 \\
\hline CZ05 & Severovýchod & 6.3 \\
\hline SI00 & Slovinsko & 6.5 \\
\hline
\end{tabular}

Source: Eurostat - Regional statistics [9], authors' calculations 
The ten regions with the lowest unemployment rate are dominated by Praha (3.9\%) and Hungarian Közép-Magyarország (4.5\%) and Nyugat-Dunántúl (5.0 \%). Further, there are three Czech regions (Střední Čechy, Jihozápad, Severovýchod), Hungarian KözépDunántúl, two Romanian regions (Nord-Est and Nord-Vest) and Slovenia. All of them reach values below $6.5 \%$. The CE10 average is $9.1 \%$ and it is the same as the EU27 average; 21 units have a lower unemployment rate, out of which 18 are also below the EU15 average, which is $8.2 \%$.

In the group of the regions below average there are three Czech regions - Střední Morava, Severozápad and Moravskoslezsko. The worst situation is in eight Polish (19.5-24.6\%) and two Slovakian regions - Stredné Slovensko (20.7 \%) and Východné Slovensko $(23.0 \%)$.

\section{Employment in Agriculture}

Employment in agriculture expresses the percentage of people employed in agriculture vis-à-vis the total employment. The regions with high employment rate in agriculture are considered to be less developed. It means the lower percentage of employment in agriculture, the more developed region.

Among the ten regions with the lowest employment in agriculture the exact half is occupied by Czech regions (Praha, Severozápad, Moravskoslezsko, Severovýchod and Střední Čechy), then there are two Hungarian regions (Közép-Magyarország, ÉszakMagyarország), and one region from Slovakia, Romania and Bulgaria. The employment in agriculture in EU15 countries is $3.68 \%$; 6 regions out of the examined ones are above the European average and the remaining 47 regions are below the average. The list is dominated by Praha (0.63 \%), Bratislavský kraj (1.31 \%), Közép-Magyarország $(1.34 \%)$ and Romanian Bucuresti-Ilfov (1.59 \%). The employment in agriculture in EU27 countries is $6.09 \%$; lower employment in agriculture is in 20 of the examined regions, higher in 33 . The CE10 average is $16.02 \% ; 36$ regions are above average, 17 are below average.

Table 9: Employment in agriculture (as a percentage of total employment, 2005)

\begin{tabular}{|ll|c|}
\hline \multicolumn{2}{|r|}{ region NUTS 2 } & $\begin{array}{c}\text { employment in } \\
\text { agriculture }\end{array}$ \\
\hline CZ01 & Praha & 0.63 \\
\hline SK01 & Bratislavský kraj & 1.31 \\
\hline HU10 & Közép-Magyarország & 1.34 \\
\hline RO32 & Bucuresti-Ilfov & 1.59 \\
\hline CZ04 & Severozápad & 2.69 \\
\hline CZ08 & Moravskoslezsko & 3.08 \\
\hline HU31 & Észak-Magyarország & 3.92 \\
\hline CZ05 & Severovýchod & 3.99 \\
\hline BG41 & Jugozapaden & 4.03 \\
\hline CZ02 & Střední Čechy & 4.09 \\
\hline
\end{tabular}

Source: Eurostat-Regional statistics [9], authors' calculations

The 10 regions with the highest proportion of employment in agriculture to the total employment include 5 Polish regions (Malopolskie, Podkarpackie, Swietokrzyskie, 
Podlaskie, Lubelskie) and 5 Romanian regions (Nord-Vest, Sud-Est, Sud-Muntenia, Nord-Est, Sud-Vest Oltenia). In these regions the percentage of employment in agriculture ranges between $23.10 \%$ and $49.01 \%$.

\section{Employment in Knowledge-Intensive Services}

The indicator of the employment in knowledge-intensive services expresses the proportion of employment in these fields to the total employment. The NACE (rev. 1.1) [10] fields which are among the knowledge-intensive services are fields with codes 61 , $62,64,65,66,67,70,71,72,73,74,80,85$ and 92 . These are for example water, air and space transport; telecommunications; financial services; activities concerning real estates and computer technology; machinery, equipment and product renting; research and development; education; health and social care; veterinary activities; and recreation, cultural and sporting activities.

The highest number of regions among the 10 regions with the largest proportion of employment in knowledge-intensive services is held by Hungarian regions (3). Like in the previous point, the first places belong to regions Praha $(41.96 \%)$, Bratislavský kraj (39.49\%) and Közép-Magyarország (37.28 \%), followed by Polish Slaskie, Estonia, Hungarian Dél-Dunántúl, Bulgarian Jugozapaden, Romanian Bucuresti-Ilfov, Hungarian Észak-Alföld and Latvia. The indicator values for EU27 or EU15 are not available for analysis. The CE10 average is $22.49 \%$; it is exceeded by 29 regions; 24 regions are below average.

Table 10: Employment in knowledge-intensive services (as a percentage of total employment, 2005)

\begin{tabular}{|ll|c|}
\hline \multicolumn{2}{|l|}{ region NUTS 2 } & employment \\
\hline CZ01 & Praha & 41.96 \\
\hline SK01 & Bratislavský kraj & 39.49 \\
\hline HU10 & Közép-Magyarország & 37.28 \\
\hline PL12 & Slaskie & 30.16 \\
\hline EE00 & Estonsko & 28.96 \\
\hline HU23 & Dél-Dunántúl & 28.22 \\
\hline BG41 & Jugozapaden & 27.83 \\
\hline RO32 & Bucuresti-Ilfov & 27.42 \\
\hline HU32 & Észak-Alföld & 26.50 \\
\hline LV00 & Lotyšsko & 25.81 \\
\hline
\end{tabular}

Source: Eurostat - Regional statistics [9]

The 10 regions with the lowest employment in knowledge-intensive services include one Polish region (Swietokrzyskie), 2 Bulgarian (Jugoiztočen, Južen Centralen) and 7 Romanian regions (i.e. all Romanian NUTS 2 regions except Bucuresti-Ilfov). The values achieved in the above-mentioned regions range between $10.12 \%$ and $19.92 \%$, and in Romania they do not go over $14.07 \%$.

\section{Employment in Research and Development}

The indicator expresses the percentage of the employees in research and development vis-à-vis the total employment. Such employees include both researchers themselves and other employees (technical and economic staff and others) of research institutions. 
The NUTS 2 regions with the highest proportion of employment in research and development are 3 Hungarian, 2 Czech and 2 Polish regions. The largest proportion is in Praha (4.02 \%), Bratislavský kraj (3.32 \%), Közép-Magyarország (2.24 \%), Romanian Bucuresti-Ilfov $(2.17 \%)$ and Polish Mazowieckie $(1.77 \%)$. These five regions are above the average of EU15 countries (1.57 \%); also region Jihovýchod $(1.49 \%)$ is above the EU27 average (1.43\%). 18 regions in total are above the CE10 average $(0.88 \%), 35$ regions are below the average.

Table 11: Employment in research and development (as a percentage of total employment, the average value of the years 2003-2005)

\begin{tabular}{|ll|c|}
\hline \multicolumn{2}{|l|}{ region NUTS 2 } & $\begin{array}{c}\text { employment } \\
\text { in R\&D }\end{array}$ \\
\hline CZ 01 & Praha & 4.02 \\
\hline SK01 & Bratislavský kraj & 3.32 \\
\hline HU10 & Közép-Magyarország & 2.24 \\
\hline RO32 & Bucuresti-Ilfov & 2.17 \\
\hline PL12 & Mazowieckie & 1.77 \\
\hline CZ06 & Jihovýchod & 1.49 \\
\hline BG41 & Jugozapaden & 1.42 \\
\hline PL21 & Malopolskie & 1.35 \\
\hline EE00 & Estonsko & 1.30 \\
\hline HU33 & Dél-Alföld & 1.17 \\
\hline HU23 & Dél-Dunántúl & 1.17 \\
\hline
\end{tabular}

Source: Eurostat - Regional statistics [9], authors' calculations

The lowest proportion of employment in research and development is in 11 regions, their values ranging from 0.17 to $0.28 \%$. These are 6 Romanian regions (Centru, Sud-Muntenia, Sud-Vest Oltenia, Nord-Vest, Nord-Est, Sud-Est), 3 Bulgarian (Jugoiztočen, Južen Centralen, Severozapaden), one region in the CR (Severozápad) and one in Poland (Swietokrzyskie).

\section{Expenditures on Research and Development}

This indicator expresses the total annual expenditures on research and development as a percentage of the gross domestic product (GERD). The expenditures include expenditures of the government, businesses, higher education institutions and private non-profit organizations. The aim of Lisbon Strategy is that the value of this indicator reaches $3 \%$ (1\% public sector, $2 \%$ private sector) before 2010 in all countries. However, this aim probably will not be met.

Out of the ten regions with the highest expenditures on R\&D four are Czech (Střední Čechy, Praha, Jihovýchod and Severovýchod). Regions Střední Čechy (2.59\%) and Praha (2.04 \%) reach values higher than the EU15 (1.91\%) and EU27 (1.84 \%) average. The first ten also include Slovenia, Hungarian Közép-Magyarország, Romanian Bucuresti-Ilfov, Polish Mazowieckie, Bulgarian Jugozapaden and Bratislavský kraj. 14 regions are above the $\mathrm{CE} 10$ average $(0.75 \%), 39$ regions are below the average. 
Table 12: Expenditures on research and development (as a percentage of the GDP, the average value of the years 2003-2005)

\begin{tabular}{|ll|c|}
\hline \multicolumn{2}{|l|}{ region NUTS 2 } & expenditures on R\&D \\
\hline CZ 02 & Střední Čechy & 2.59 \\
\hline CZ 01 & Praha & 2.04 \\
\hline SI 00 & Slovinsko & 1.39 \\
\hline HU10 & Közép-Magyarország & 1.34 \\
\hline RO32 & Bucuresti-Ilfov & 1.14 \\
\hline PL12 & Mazowieckie & 1.14 \\
\hline CZ06 & Jihovýchod & 1.14 \\
\hline BG41 & Jugozapaden & 1.02 \\
\hline SK01 & Bratislavský kraj & 1.00 \\
\hline CZ05 & Severovýchod & 0.98 \\
\hline
\end{tabular}

Source: Eurostat - Regional statistics [9], authors' calculations

The other side of the ranking ( $R \& D$ expenditures below $0.20 \%$ ) is occupied by some Polish regions (Zachodniopomorskie, Lubuskie, Opolskie, Swietokrzyskie), Bulgarian (Južen Centralen, Severen Centralen, Jugoiztočen, Severozapaden) and Romanian (Centru, Sud-Est, Nord-Vest, Nord-Est, Sud-Vest Oltenia) regions. Their proportion of expenditures to GDP is between $0.07 \%$ and $0.18 \%$, which puts them deep below the CE10 average.

Regional Synthesis of the Development Potential

The results of the synthesis, presented in the following table and figure, document the existing differences or disparities among the individual regions at the level of socioeconomic development.

Table 13: Regional Synthesis of the Development Potential

\begin{tabular}{|ll|c|}
\hline region NUTS 2 & assessment \\
\hline CZ01 & Praha & 4.8 \\
\hline HU10 & Közép-Magyarország & 4.6 \\
\hline SI00 & Slovenija & 4.6 \\
\hline SK01 & Bratislavský kraj & 4.6 \\
\hline CZ02 & Strední Cechy & 4.4 \\
\hline CZ06 & Jihovýchod & 4.2 \\
\hline PL12 & Mazowieckie & 4.0 \\
\hline CZ05 & Severovýchod & 3.8 \\
\hline CZ03 & Jihozápad & 3.6 \\
\hline RO32 & Bucuresti-Ilfov & 3.6 \\
\hline BG41 & Jugozapaden & 3.2 \\
\hline CZ07 & Strední Morava & 3.2 \\
\hline EE00 & Estonia & 3.2 \\
\hline HU21 & Közép-Dunántúl & 3.0 \\
\hline HU22 & Nyugat-Dunántúl & 3.0 \\
\hline HU32 & Észak-Alföld & 3.0 \\
\hline HU33 & Dél-Alföld & 3.0 \\
\hline
\end{tabular}




\begin{tabular}{|c|c|}
\hline region NUTS 2 & assessment \\
\hline PL21 Malopolskie & 3.0 \\
\hline CZ08 Moravskoslezsko & 2.8 \\
\hline HU23 Dél-Dunántúl & 2.8 \\
\hline LT00 Lithuania & 2.8 \\
\hline LV00 Latvia & 2.6 \\
\hline $\begin{array}{ll}\text { PL41 Wielkopolskie } \\
\end{array}$ & 2.6 \\
\hline CZ04 Severozápad & 2.4 \\
\hline PL22 Slaskie & 2.4 \\
\hline Dolnoslaskie & 2.4 \\
\hline PL63 Pomorskie & 2.4 \\
\hline SK02 Západné Slovensko & 2.4 \\
\hline PL11 Lódzkie & 2.2 \\
\hline Opolskie & 2.2 \\
\hline SK04 Východné Slovensko & 2.2 \\
\hline HU31 Észak-Magyarország & 2.0 \\
\hline PL42 Zachodniopomorskie & 2.0 \\
\hline Lubuskie & 2.0 \\
\hline Kujawsko-Pomorskie & 2.0 \\
\hline PL62 Warminsko-Mazurskie & 2.0 \\
\hline SK03 $\quad$ Stredné Slovensko & 2.0 \\
\hline PL31 $\quad$ Lubelskie & 1.8 \\
\hline BG33 Severoiztochen & 1.6 \\
\hline BG34 Jugoiztočen & 1.6 \\
\hline Podkarpackie & 1.6 \\
\hline PL34 $\quad$ Podlaskie & 1.6 \\
\hline $\begin{array}{ll}\text { RO11 } & \text { Nord-Vest } \\
\end{array}$ & 1.6 \\
\hline RO12 Centru & 1.6 \\
\hline RO22 Sud-Est & 1.6 \\
\hline $\begin{array}{ll}\text { RO31 } & \text { Sud-Muntenia }\end{array}$ & 1.6 \\
\hline BG31 Severozapaden & 1.4 \\
\hline PL33 Swietokrzyskie & 1.4 \\
\hline RO21 Nord-Est & 1.4 \\
\hline RO41 Sud-Vest Oltenia & 1.4 \\
\hline RO42 Vest & 1.4 \\
\hline BG32 Severen Centralen & 1.2 \\
\hline BG42 Južen Centralen & 1.2 \\
\hline
\end{tabular}

Source: Eurostat - Regional statistics [9], authors' calculations

The 'best' group with the largest development potential includes the regions of V4 capitals, the first being Praha, followed by Slovenia and two Czech regions. The next group mainly includes the most developed non-metropolitan regions of Hungary and the Czech Republic (together with one Polish region), Estonia - the most developed Baltic country, and metropolitan regions of the countries which are the least developed economically - Romania and Bulgaria. The third group, with the highest number of members, consists of the remaining Czech and Hungarian regions together with the 
crucial majority of Polish and Slovakian regions, and with Latvia and Lithuania. The 'worst' group contains all non-metropolitan Romanian and Bulgarian regions and four Polish regions at the eastern border.

\section{Figure 2: Regional Synthesis of the Development Potential}

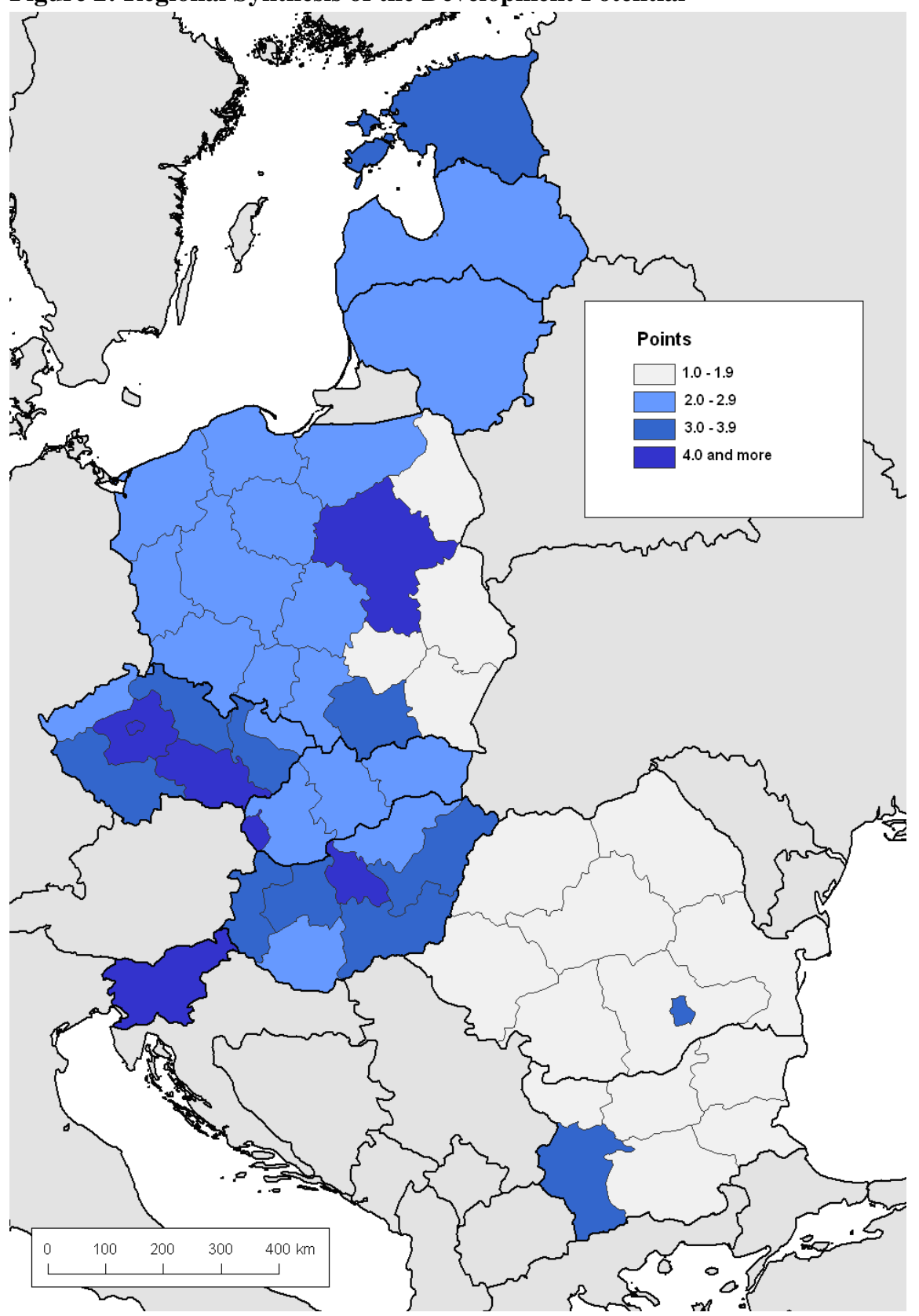

Source: created by authors on the basis of Eurostat - Regional statistics [9] 
From a more detailed perspective we can conclude that the development potential of individual regions naturally corresponds with the level of their total economic development. The obtained results indicate that the more developed countries have entered or are entering the integration stage of economic development, characterized by the diffusion of the positive effects from the most developed regions (including the regions of the economically more advanced neighbouring "western" countries), which strengthens the natural tendencies towards the convergence of the economic standard. However, this is a largely generalized conclusion, verification of which would demand much more detailed analyses (including a reflection on the influence of inertia in socioeconomic development and developmental specifics of the individual countries e.g. Slovakia with the extreme position of the capital) which is beyond the scope of this study.

\section{Conclusion}

The above-mentioned facts logically play an important role in the choice of the optimal strategy for the regional policy, determined predominantly in CE10 countries by the EU Economic and Social Cohesion policy (cohesion policy). The basic issue is mainly the perception of the future structure of CE10 cohesion policies from the point of view of the balance between the Convergence Objective and the Competitiveness Objective (e.g. in the Czech Republic we can assume that the criteria for inclusion in the Convergence Objective will not be met by another one or two NUTS 2 regions). Therefore, there are the following key questions to consider:

- taking account of expert analyses so that higher efficiency of public resources allocation is achieved while their complementarity with the effects of market mechanisms is respected (especially by means of effective combinations of the indirect and direct support of economic development);

- optimization of the factual content of partial objectives under the cohesion policy main objective aimed at convergence, based on the complex assessment of territorial business environment quality factors and on the emphasis on the activation of new, or rather inefficiently used endogenous sources of development;

- $\quad$ stimulation of the creation and transfer of innovations by means of the development of education at the level of system and the support for the cooperation of the entrepreneurial and the public sectors in relation to the cohesion policy main objective focused on competitiveness;

- $\quad$ support for the processes of territorial integration providing higher synergy of the cohesion policy partial objectives (inducing the creation of the mechanism of its incorporation in the project selection process using relevant criteria) in relation to the cohesion policy main objective focused on territorial cooperation;

- strengthening the significance of life quality components, especially in the framework of the cohesion policy main objective aimed at competitiveness.

\section{References}

BEHRENS, A. (2003). Income of private households and gross domestic product in Europe's regions. Statistics in focus, General statistics, Theme 1-7/2003. ISSN 15614875. 
Council Regulation (EC) No 1083/2006 of 11 July 2006 laying down general provisions on the European Regional Development Fund, the European Social Fund and the Cohesion Fund and repealing Regulation (EC) No 1260/1999.

European Commision. (1996). Regional development studies - The impact of the development of the countries of Central and Eastern Europe on the Community territory. Luxembourg: Office for Official Publications of the European Communities.

European Commission. (2006). Community Strategic Guidelines for Cohesion policy.

European Commission. Regional Policy - Employment, Social Affair and Equal Opportunities. Retrieved from http://ec.europa.eu/employment_social

European Commission. Regional Policy - InfoRegio. Dostupné na http://ec.europa.eu/regional_policy

Eurostat. (2007). Eurostat regional yearbook 2007. Luxembourg: Office for Official Publications of the European Communities. ISSN 1681-9306.

Eurostat. Retrieved from http://epp.eurostat.ec.europa.eu

Eurostat: Regional statistics. Retrieved from http://epp.eurostat.ec.europa.eu.

ČSÚ: Klasifikace ekonomických činností (CZ-NACE). Retrieved from http://www.czso.cz/csu/klasifik.nsf/i/klasifikace_ekonomickych_cinnosti_(cz_nace).

Ministerstvo pro místní rozvoj: Fondy Evropské unie. Retrieved from www.strukturalnifondy.cz

Ministerstvo pro místní rozvoj (1997): Nadnárodní perspektivy evropského územního rozvoje (translated as Cooperation for European territorial development - Europe 2000+, Praha.

\title{
REGIONAL ANALYSIS OF NEW EU MEMBER STATES IN THE CONTEXT OF COHESION POLICY
}

\section{Milan Viturka, Vladimír Žítek, Viktorie Klímová, Petr Tonev}

Ekonomicko-správní fakulta Masarykovy univerzity, katedra regionálního rozvoje a správy, Lipová 41a, 60200 Brno (viturka@econ.muni.cz; zitek@econ.muni.cz; Viktorie.Klimova@econ.muni.cz; Petr.Tonev@econ.muni.cz)

\begin{abstract}
The paper concentrates on the new European Union member states, i.e. the states of central and eastern Europe which entered the Union in 2004 (Czech Republic, Slovakia, Poland, Hungary, Lithuania, Latvia, Estonia and Slovenia) and 2007 (Bulgaria and Romania). The basis of the paper is the evaluation of the cohesion policy in the countries in question, which are then analysed at the level of NUTS 2 regions (cohesion regions). The aim of the socioeconomic analysis is to assess the economic level of the regions and to use the results to form their typology. Ten characteristic indicators were chosen so that the study was as complex as possible. For each indicator in the examined countries the average was calculated, which allowed for a considerable increase of the information relevance of the study conclusions. For the cartographic representation of the regional differentiation intervals based on this average and the standard deviation
\end{abstract}


were used. The final part of the study presents a concluding synthesis together with the above-mentioned typology of the regions. The results are interpreted in the context of the optimal strategy selection for the regional policy determined by the EU cohesion policy.

Key words: region, regional disparities, socioeconomic development, cohesion policy, new member states,

Abstrakt: Příspěvek je zaměřen na nové členské země Evropské unie, a to státy střední a východní Evropy, které vstoupily do unie v roce 2004 (Česko, Slovensko, Polsko, Mad'arsko, Litva, Lotyšsko, Estonsko a Slovinsko) a v roce 2007 (Bulharsko a Rumunsko). Východiskem příspěvku je hodnocení kohezní politiky v daných zemích, které jsou následně analyzovány na regionální úrovni NUTS 2 (regiony soudržnosti). Cílem realizované socioekonomické analýzy je zhodnotit ekonomickou úroveň regionů a na jejím základě následně sestavit jejich určitou typologii. Bylo vybráno deset ukazatelů charakterizujících regiony tak, aby studie byla pokud možno komplexní. Pro všechny zahrnuté ukazatele je pak vypočítán průměr pro hodnocené země, který umožnil významně zvýšit vypovídací schopnost závěrů celé studie. Pro kartografické znázornění regionální diferenciace je využito intervalů založených právě na průměru a směrodatné odchylce. Studie je uzavřena závěrečnou syntézou zahrnující zmíněnou typologii regionů. Zjištěné výsledky jsou interpretovány v kontextu výběru optimální strategie regionální politiky, determinované kohezní politikou EU.

\section{Klíčová slova}

Region, regionální disparity, socioekonomický rozvoj, kohezní politika, nové členské státy

JEL classification: 018, R11, R58

DOI: $10.2478 / v 10135-009-0001-8$ 